ARQGA/1204

\title{
CURATIVE RESECTION PLUS ADJUVANT CHEMOTHERAPY FOR EARLY STAGE PRIMARY GASTRIC NON-HODGKIN'S LYMPHOMA: a retrospective study with emphasis on prognostic factors and treatment outcome
}

\author{
Jaques WAISBERG ${ }^{1}$, Eduardo Antonio ANDRÉ ${ }^{1}$, Maria Isete Fares FRANCO ${ }^{2}$, \\ Júlio Zaki ABUCHAM-NETO ${ }^{1}$, Daniela WICKBOLD ${ }^{1}$ and Fábio Schmidt GOFFI ${ }^{1}$
}

ABSTRACT - Background - There is controversy regarding the optimal therapy for primary non-Hodgkin gastric lymphoma with some authors defending surgical extirpation either alone or in association with radiotherapy and or chemotherapy, especially in relation to the earlier stages of the disease. Aim - To analyze the clinical-pathological features and the results of management approaches for patients with primary early-stage non-Hodgkin's lymphoma of the stomach operated in Surgical Gastroenterology Department, "Hospital do Servidor Público Estadual", São Paulo, SP, Brazil. The literature is reviewed to highlight the aspects of diagnosis, prognostic factors and role of the various treatment regimens. Method - Sixteen patients with primary early-stage gastric lymphoma underwent curative surgical treatment. The variables analyzed were age, sex, location, size, type of surgery, number of lesions, depth of invasion, histological type in accordance with Kiel's classification, involvement of lymph nodes, Ann Arbor stage classification modified by Musshoff and Schmidt-Vollmer, histological grade, margins, adjuvant therapy, clinical course and survival. Results - Ten patients (62.5\%) underwent subtotal gastrectomy and six (37.5\%) underwent total gastrectomy. The majority $(9 / 56.2 \%)$ of the lesions were located in the antrum. Single lesions (10/62.5\%) were more frequent than multiple lesions (6/37.5\%). Thirteen patients (81.2\%) were classified as stage IE and three (18.7\%) as stage IIE1. Primary gastric lymphoma classified histologically as low or high grade was presented by $10(62.5 \%)$ and $6(37.5 \%)$ patients, respectively. The most frequent histological types were the lymphoplasmocytic cytoid (4/25.0\%) and centroblastic (4/25.0\%). Ten patients $(62.5 \%)$ received adjuvant treatment (chemotherapy and/or radiotherapy). Nine patients (56.2\%), all in stage IE, reached a survival greater than 5 years and of these eight $(50.0 . \%)$ had received adjuvant therapy. Two (12.5\%) patients with stage IIE1 presented peritoneal relapse and died 3.0 years and 3.5 years after their respective operations. The mean overall survival was 42,5 months. Conclusions - Among the patients with primary early-stage gastric lymphoma (IE and IIE1), the gastric resection enabled an accurate clinicopathological staging, in addition to obtaining sufficient material for histopathological study and extirpation of the lesion. Furthermore, for patients with stage IE disease, the gastric resection combined with adjuvant therapy was associated with a greater than 5-year survival. Until prospective randomized studies are realized in order to evaluate the real efficacy of the different types of treatment for primary early-stage gastric lymphoma, management approaches should be individually tailored.

HEADINGS - Lymphoma. Non-Hodgkin’s lymphoma. Gastric neoplasms. Prognostic factors. Survival.

\section{INTRODUCTION}

Primary gastric lymphoma represents more than half of all primary gastrointestinal lymphomas in the western world, accounting for $2 \%$ to $7 \%$ of all malignant tumors of the stomach, and an increasing incidence has been reported ${ }^{(1,2,3,4)}$.
There is still controversy over the optimal treatment in relation to the earlier stages of the disease particularly regarding the role of surgery ${ }^{(8,11,16,28)}$. The best treatment for the earlier stages has not been defined due to a lack of major prospective trials and the heterogeneity of retrospectives series, which, in some cases, analyzed all stages together or included patients with intestinal

Surgical Gastroenterology and ${ }^{2}$ Pathology Departments, "Hospital do Servidor Público Estadual", São Paulo, SP, Brazil

Address for correspondence: Dr. Jaques Waisberg - Rua das Figueiras, 550 — apt. 134 - 09080-300 - Santo André, SP, Brazil. E-mail: jaqueswaisberg@uol.com.br 
lymphomas, mucosa-associated lymphoid tissue (MALT) and low-grade lymphomas ${ }^{(12,16,27,28,31)}$.

Due to the relative rarity of the tumor, few centers have accumulated an adequate number of patients to generate meaningful data and thereby develop rational treatment protocols. In addition to this, the use of different primary gastric lymphoma staging and histopathological classification models has made it difficult to perform comparative analyses of their results.

Surgical resection of these tumors is important for diagnosis, and although extirpation of the lesion is potentially curative, it has been reported that around $50 \%$ of patients with primary early-stage gastric lymphoma present relapse when treated by

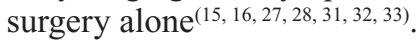

Studies have predominantly included patients, whose disease was already at a late stage, thereby making it difficult to evaluate the potential effect on patient survival of curative extirpation of localized primary gastric lymphoma ${ }^{(2,3,28,36,37)}$.

Thus, the objective of this study was to describe the clinicalpathological features and the results of management of patients with primary early-stage non-Hodgkin's lymphoma of the stomach that underwent curative surgical treatment in our Department. In addition the literature is reviewed to highlight the various aspects of diagnosis, prognostic factors and the role of different treatment modalities.

\section{METHODS}

A total of 33 patients with primary gastric lymphoma confirmed by histopathological examinations were treated in the Department of Surgical Gastroenterology, "Hospital do Servidor Público Estadual", São Paulo, SP, Brazil, during the 28-year period from 1973 to 2001 . Of these, 17 were excluded from the study for the following reasons: 6 were not operated in view of serious associated diseases; 4 patients underwent palliative operations; 7 presented advanced-stage disease. Thus, the data from this sample represents a review of 16 patients with primary gastric lymphoma in initial stage, which underwent curative surgical treatment, 10/16 in association with postoperative chemotherapy and/or radiotherapy.

The term curative surgery implied the macroscopic absence of residual disease at the end of the surgical procedure and in the anatomopathological exam of the resected lesion. The clinical course of these patients was obtained from a review of the hospital records and from interviews with the patients or their relatives. Postoperative complications were defined as those that occurred within 30 days after the surgical intervention. The survival was calculated from the time of the operation until the last follow-up or death.

Twelve (75.0\%) of the patients were male and four $(25.0 \%)$ were female, resulting in a male/female ratio of $3: 1$. The mean age of the patients was 62.8 years, ranging from 40 to 83 years (Table 1). All the patients were caucasian.

The disease was staged using the Ann Arbor system for non-Hodgkin's lymphomas, as modified by MUSSHOFF and SCHMIDT-VOLLMER ${ }^{(21)}$. Stage IE primary gastric lymphoma was defined as the presence of lymphoma involving the stomach in the absence of any lymph node involvement. Stage IIE1 includes patients with lymph node involvement in the perigastric region. Stages IE and IIE1 were considered to be the early stages. Late stage was defined as the presence of metastases in unilateral subdiaphragmatic regional lymph nodes (stage IIE2), the presence of metastases in bilateral sub-diaphragmatic regional lymph nodes (stage IIIE), or the presence of hematogenic dissemination with involvement of the stomach and one or more extra-lymphatic organs (stage IVE).

The staging was done from the physical examination findings, gastroscopy and the respective biopsy, bone marrow biopsies, contrast radiography of the stomach, ultrasonography, computed tomography of the thorax and abdomen, laparotomy and histopathological examination of specimens from the surgical extirpation. Each neoplasm was classified as primary to the stomach in accordance with the criteria of DAWSON et al. ${ }^{(7)}$ : an absence of superficial palpable lymphadenopathy in the initial clinical presentation, an absence of mediastinal lymph node involvement in radiography of the thorax, total and differential leukocyte count with normal values, a lesion limited to the stomach and regional lymph nodes, and an absence of tumor in the liver and spleen.

The original slides were reviewed by a pathologist and, whenever necessary, new sections were cut from the paraffin blocks. The lymphomas were histologically classified in accordance with Kiel's system.

With regard to the degree of malignancy, low-grade lymphomas were considered to be those that presented proliferation of centrocytic cells or small cells. High-grade lymphomas were considered to be lesions that displayed centroblastic or largecell proliferation.

The extent of the gastric extirpation varied according to the location of the lesion. It was total, or extended total in association with splenectomy and caudal pancreatectomy, for tumors located in the body or cardia, and subtotal for those located in the antrum. The extent of the lymphadenectomy was R1 standard until the first half of the 1990's and then R2 standard in recent years.

The decision regarding adjuvant therapy was made in collaboration with the consulting oncologist and often reflected that physician's personal preference and the drugs disposable at the time of treatment. The chemotherapy protocols indicated for the control of microscopic residual disease were: CHOP (cyclophosphamide $750 \mathrm{mg} / \mathrm{m}^{2}$, doxorubicin $50 \mathrm{mg} / \mathrm{m}^{2}$, vincristine $1.4 \mathrm{mg} / \mathrm{m}^{2}$ via intravenous route and prednisone $60 \mathrm{mg} / \mathrm{m}^{2}$ orally, administered on days 1 to 5), CHOP plus bleomycin $10 \mathrm{mg} / \mathrm{m}^{2}$ via intravenous route, and CHOP plus BACOP (bleomycin $10 \mathrm{mg} / \mathrm{m}^{2}$, adriamycin $60 \mathrm{mg} / \mathrm{m}^{2}$, cyclophosphamide $750 \mathrm{mg} / \mathrm{m}^{2}$, vincristine $1.4 \mathrm{mg} / \mathrm{m}^{2}$ and prednisone $60 \mathrm{mg} / \mathrm{m}^{2}$ orally, administered on days 1 to 5). Radiotherapy, when applied, was at a standard dose of 2000 to 4000 cGy.

Quantitative variables were represented by absolute frequency (n) and relative frequency (\%). Considering the nature of the samples, the statistical models utilized were arithmetic mean. Patients' survival was analyzed using the Kaplan-Meier method. 


\section{RESULTS}

The mean time elapsed between onset of symptoms and the surgical treatment was 11.3 months, ranging from 1.3 to 24 months. The most frequent symptoms were epigastric pain (75.0\%), upper digestive tract hemorrhage (50.0\%), weight loss $(50.0 \%)$, asthenia $(37.5 \%)$ and vomiting $(31.2 \%)$. The mean weight loss was $8.3 \mathrm{~kg}$. Physical examination of the patients in this study did not reveal any abnormalities.

Gastroscopy and the respective biopsy were performed on 14 patients $(87.5 \%)$, i.e. an average of 1.3 examinations per patient. In four patients (25.0\%), the diagnosis was "carcinoma" and in another three patients (18.7\%) there was a suspicion of lymphoma. Among the remaining seven (43.7\%) patients, the histopathological study revealed "chronic gastritis", although the endoscopic appearance suggested malignancy of the gastric lesion. Two patients who did not undergo gastroscopy had a diagnostic suspicion of gastric neoplasm on the basis of findings from contrast radiology of the stomach.

Four patients $(25.0 \%)$ were examined using computed tomography, which revealed thickening of the gastric wall in one patient and no anomalies in the remainder. Four patients (25.0\%) underwent bone marrow biopsy and the results were all normal. All the patients had their definitive diagnosis established by the histopathological study of the product from the gastric extirpation.

Ten patients $(62.5 \%)$ underwent subtotal gastrectomy and six $(37.5 \%)$ underwent total gastrectomy, in association with removal of the spleen and the tail of the pancreas in two (12.5\%) cases (Table 1).

Five patients (31.2\%) presented one or more of the following postoperative complications: anastomotic fistula in three, bronchopneumonia in three, acute respiratory insufficiency in two, and stenosis of the esophageal-jejunal anastomosis, peritonitis, pleural empyema and acute renal insufficiency in one case each. The patient who presented late stenosis of the esophageal-jejunal anastomosis was successfully treated with endoscopic dilatation. Four patients $(25.0 \%)$ died because of postoperative complications: respiratory insufficiency in three and septic shock in one patient.

The lesion was located in the antrum in nine patients $(56.2 \%)$, in the gastric body in six cases (37.5\%) and in the cardia in one case $(6.2 \%)$ (Table 1$)$.

The mean of the largest dimension of the tumor was $4.8 \mathrm{~cm}$, ranging from 1.0 to $10.0 \mathrm{~cm}$ (Table 2). The lesions located more proximally in the stomach (cardia and gastric body) presented a greater mean diameter $(5.9 \mathrm{~cm})$ than those located more distally $(3.9 \mathrm{~cm})$. There was a single lesion in 10 patients $(62.5 \%)$ and multiple lesions (two or more) in 6 patients (37.5\%) (Table 2).

The predominant macroscopic appearance of the neoplasm was ulcerative in nine cases $(56.2 \%)$, followed by infiltrativeulcerative in three cases $(18.7 \%)$, vegetative-ulcerative in two cases $(12.5 \%)$ and infiltrative in one patient $(6.2 \%)$.

The neoplasm invaded the tunica muscularis of the stomach in eight patients $(50.0 \%)$, the serous membrane in five cases $(31.2 \%)$ and reached the adjacent adipose tissue in three cases (18.7\%) (Table 2). The surgical margin was involved by the neoplasm in one patient $(6.2 \%)$ (Case 4$)$.

In accordance with Kiel's classification, the most frequent histological types were lymphoplasmocytic cytoid $(4 / 25.0 \%)$ and centroblastic $(4 / 25.0 \%)$, followed by lymphocytic $(3 / 18.7 \%)$, centrocytic-centroblastic (2/12.5\%), centrocytic $(2 / 12.5 \%)$ and immunoblastic (1/6.2\%) (Table 2). Eleven patients (68.7\%) presented histological low-grade primary gastric lymphoma, while another five patients (31.2\%) presented histological highgrade primary gastric lymphoma (Table 2 ).

Thirteen patients ( $81.2 \%)$ were classified as stage IE and three patients (18.7\%) as stage IIE1 (Table 2). All nine patients (56.2\%) who achieved a survival greater than 5 years and one with 1 year of disease free survival did not present involvement of the lymph nodes (stage IE). On the other hand, two patients $(16.6 \%)$ with involvement of the lymph nodes (stage IIE1) presented peritoneal relapse and died after 3.0 years and 3.5 years after their operations, in both cases due to carcinomatosis (Table 1).

TABLE 1 - Main clinical aspects, morphological features and treatment modalities of the cases of early-stage primary gastric lymphoma

\begin{tabular}{|c|c|c|c|c|c|c|c|}
\hline Case & Age & Sex & Location & Size $(\mathrm{cm})$ & Surgery & Adj ther & No. lesions \\
\hline 1 & 69 & Male & Cardia & 10 & Total & None & Single \\
\hline 2 & 40 & Female & Antrum & 1.2 & Subtotal & СНTP & Multiple \\
\hline 3 & 48 & Female & Antrum & 6.0 & Subtotal & CHTP & Single \\
\hline 4 & 74 & Female & Antrum & 1.8 & Subtotal & RDTP & Multiple \\
\hline 5 & 59 & Male & Body & 7.5 & Subtotal & $\mathrm{CHTP}+\mathrm{RDTP}$ & Single \\
\hline 6 & 77 & Male & Antrum & 6.0 & Subtotal & СHTP & Single \\
\hline 7 & 53 & Male & Antrum & 2.5 & Subtotal & CHTP & Multiple \\
\hline 8 & 53 & Male & Antrum & 2.0 & Total & СHTP & Multiple \\
\hline 9 & 79 & Male & Body & 8.0 & Total & None & Single \\
\hline 10 & 67 & Male & Antrum & 7.0 & Subtotal & None & Single \\
\hline 11 & 43 & Male & Body & 1.2 & Subtotal & None & Single \\
\hline 12 & 63 & Male & Body & 7.5 & Total & СHTP & Multiple \\
\hline 13 & 73 & Male & Body & 6.0 & Total & None & Single \\
\hline 14 & 54 & Male & Antrum & 8.0 & Subtotal & CHTP & Single \\
\hline 15 & 83 & Male & Antrum & 1.0 & Subtotal & None & Multiple \\
\hline 16 & 70 & Female & Body & 1.3 & Total & CHTP & Single \\
\hline
\end{tabular}

Adj ther = adjuvant therapy; CHTP = chemotherapy; RDTP = radiotherapy; No. lesions = number of lesions 
TABLE 2 - Main morphological features, outcome and survival of the cases of early-stage primary gastric lymphoma

\begin{tabular}{|c|c|c|c|c|c|c|c|c|}
\hline Case & Depth & Histological Type & LN & Staging & Margins & Grade & Outcome & Survival \\
\hline 1 & Serosa & Lymphocytic & Compr & IIE1 & Free & Low & Death & 3.5 years \\
\hline 2 & Muscle & Lymphopl/cytd & Free & IE & Free & Low & Alive & $>5$ years \\
\hline 3 & Muscle & Centroblastic & Free & IE & Free & High & Alive & $>5$ years \\
\hline 4 & Serosa & Centrobl/ccytc & Free & IE & Compr & Low & Alive & $>5$ years \\
\hline 5 & Muscle & Lymphopl/cytd & Free & IE & Free & Low & Alive & $>5$ years \\
\hline 6 & Serosa & Centrocytic & Compr & IIE1 & Free & Low & Death & 3 years \\
\hline 7 & Fatty tissue & Lymphocytic & Free & IE & Free & Low & Alive & $>5$ years \\
\hline 8 & Fatty tissue & Lymphopl/cytd & Free & IE & Free & Low & Alive & $>5$ years \\
\hline 9 & Serosa & Centrocytic & Compr & IIE 1 & Free & Low & Death & 18 days \\
\hline 10 & Serosa & Centroblastic & Free & IE & Free & High & Death & 18 days \\
\hline 11 & Muscle & Centroblastic & Free & IE & Free & Low & Alive & $>5$ years \\
\hline 12 & Muscle & Immunoblastic & Free & IE & Free & High & Alive & $>5$ years \\
\hline 13 & Muscle & Lymphopl/cytd & Free & IE & Free & Low & Death & 1 month \\
\hline 14 & Fatty tissue & Centrobl/ccytc & Free & IE & Free & High & Alive & $>5$ years \\
\hline 15 & Muscle & Lymphocytic & Free & IE & Free & Low & Death & 12 days \\
\hline 16 & Muscle & Centroblastic & Free & IE & Free & High & Alive & $>5$ years \\
\hline
\end{tabular}

Out of the 12 patients that survived more than 1 month, 10 $(83.3 \%)$ received adjuvant treatment: $8 / 10(50.0 \%)$ chemotherapy, $1 / 10(6.2 \%)$ radiotherapy and $1 / 10(6.2 \%)$ received both chemotherapy and radiotherapy. The remaining two patients $(12.5 \%)$ refused adjuvant treatment (Table 1). One of them (case 1), submitted to the total gastrectomy, presented a voluminous neoplasia in cardia that penetrated until the serosa of the organ, with perigastric lymph nodes involvement (stage IIE2). It presented peritoneal relapse and died with carcinomatosis 3.5 years after the operation. Case 11 , submitted to subtotal gastrectomy, presented a small lesion in the gastric body that penetrated until the muscular layer of the wall of the organ, without lymph nodes involvement (stage IE). He survived more than 5 years, without active disease. The mean global survival was 42.5 months.

\section{DISCUSSION}

Primary gastric lymphoma arises from the mucosal or submucosal layer and spreads diffusely into the mucosa and submucosa, and the tumor extends along the surface of the gastric wall, usually without lymph node involvement ${ }^{(6,17,35)}$. In this situation, gastroscopy may not be capable of detecting the lesion, due to the lack of suggestive alterations, such as polypoid or ulcerated lesions or also diffuse thickening of gastric folds ${ }^{(14,30)}$. Initial gross finding of gastric lymphoma may mimic various gastric lesions, such as peptic ulcer diseases, gastritis and primary gastric carcinoma. Although a dense lymphoid infiltrate is the most consistent feature of gastric lymphomas, it is not reliable as a marker of lymphoma ${ }^{(30)}$. In the present study, these characteristics of primary gastric lymphoma may explain the absence of endoscopic and histopathological detection of primary gastric lymphoma in an initial stage in the majority of cases during the preoperative period.

Endoscopic ultrasonography has become the tool to evaluate the depth of the tumor in gastric cancer or lymphoma. However, sensitivity or specificity of the enlarged lymph node varies from one study to another ${ }^{(5)}$.
The ideal treatment for primary early-stage gastric lymphoma continues to be controversial ${ }^{(3,9,15,16,19,28)}$. Surgical extirpation, chemotherapy and radiotherapy have been utilized in association or alone $\mathrm{e}^{(2,3,13,24,25)}$. Surgical treatment is preferred for the following reasons: (i) more representative samples for histological diagnosis and consequent classification can be obtained; (ii) the risk of serious hemorrhages or perforation of the gastric wall during chemotherapy or radiotherapy treatment of non-removed tumors is eliminated; (iii) more accurate staging; (iv) the possibility of removing lesions before initiating adjuvant chemotherapy and/or radiotherapy increases the chances of success of the treatment; and (v) relief of symptoms $s^{(2,4,15,16,28)}$. One of the principal advantages of staging via laparotomy with gastrectomy is the capability of accurately discriminating between stage IE, IIE1 and IIE2 lesions, as lymph nodes adjacent to the stomach cannot generally be accurately visualized by non-invasive methods $(2,8,15,16$.

The extent of surgical extirpation utilized in the cases of this series involved total or subtotal gastrectomy, with regional lymphadenectomy ${ }^{(2,3,4,15,16)}$. With regard to splenectomy, this was done in association with total gastrectomy in cases of lesions of the gastric cardia and gastric body involving the serous membrane because of the high incidence of metastases in the lymph nodes of the hilum of spleen ${ }^{(4,15,16)}$. On the other hand, in cases of primary gastric lymphoma located in the lower third of the stomach, the spleen was spared, provided that it was not grossly involved ${ }^{(2,3,4,15)}$.

Debulking of advanced disease was associated with high morbidity and mortality and low response rates of $6 \%-40 \%{ }^{(1,15,16 \text {, }}$ 28). Operative mortality was between $3 \%-25 \%$ with higher rates for palliative procedures, which were performed for symptomatic relief, removal of tumor mass and avoidance of hemorrhage or

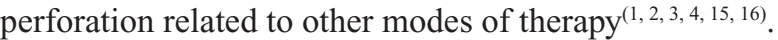

The morbidity, mortality and impairment of life quality generated by gastric resection have led some investigators to avoid gastrectomy, opting instead to treat patients with a conservative $\operatorname{approach}^{(10,19,20,24,25,26,29)}$.

A prospective study ${ }^{(26)}$ has found that in stages IE and IIE, the complete response, survival rate and disease free survival 
rates were similar to those who underwent complete resection and partial or no surgery prior to administration of chemotherapy. Survival rates of $60 \%$ with surgery alone compared to $85 \%$ if adjuvant chemotherapy was used have been reported ${ }^{(26)}$. In other studies $^{(10,19,20,34)}$, the mortality and morbidity related to surgery were similar if not greater than those related to non-surgical treatment for stage I and II. In patients with comorbid factors and increased risk of surgery-related morbidity and mortality, chemotherapy offered an effective or equally effective mode of treatment to surgical resection ${ }^{(24,25,26)}$. Series have shown the superiority of combined surgery and chemotherapy to single mode with survival rates reaching $86 \%-94 \%$ for stages IE and $\operatorname{IIE}^{(13,31,34)}$. In these series, the survival rates were higher for those who underwent complete resection; thus resection was the most important variable and major determinant of prolonged complete remission.

Surgery can be performed with a low complication rate, and result in satisfactory patient survival in stage I disease ${ }^{(2,15,31,33)}$. In stage II disease, surgical curability did not affect the survival, implying the necessity for randomized studies to evaluate treatment strategies ${ }^{(2,3,28,31,33)}$. However, considering the stage migration after histological examination and possible inaccuracy of preoperative staging, the choice of non-surgical treatment must be considered with care ${ }^{(31)}$.

Studies have recommended adjuvant therapy (chemotherapy and/or radiotherapy) for patients with primary gastric lymphoma invading the serous membrane, with involvement of the surgical margins or infiltrated lymph nodes ${ }^{(4,15,16,28,34)}$. Although there have been reports of apparent cure of primary gastric lymphoma with a single resection, these should be considered with caution, since initial dissemination may be undetectable despite an exhaustive staging ${ }^{(2,8,16,29)}$. Thus, postoperative chemotherapy may be used to inhibit recurrence of neoplasm in the remaining stomach and eradicate microscopic residual disease ${ }^{(16,23,29)}$.

Radiotherapy directed towards the framework supporting the stomach and the para-aortic lymph nodes has been demonstrated to be beneficial for patients with involvement of lymph nodes and disease that is locally advanced or cannot be extirpated ${ }^{(13,17)}$. Radiation was used post-operatively in high- and low-grade lymphomas, for any residual tumors in stages I and II in order to improve the disease free survival ${ }^{(17)}$. Nevertheless, the use of radiotherapy in the treatment of primary gastric lymphoma remains controversial, given the absence of randomized and prospective studies evaluating its efficacy, especially as an isolated treatment.

In general, the decision regarding the adjuvant therapy reflected the personal preference of the oncologist. Case 4, an elderly patient with comorbidity that did not allow the patient to receive adjuvant chemotherapy, was submitted to the adjuvant radiotherapy due to the compromised surgical margin. Case 5 presented a large lesion in the gastric body and was submitted to subtotal gastrectomy associated with adjuvant chemotherapy and radiotherapy. Nowadays, in the patients submitted to the curative resection of the primary gastric lymphoma in initial stage, we indicated adjuvant chemotherapy to eradicate microscopic residual disease.
Helicobacter pylori (H. pylori) infection has been documented in up to $90 \%$ of patients with low-grade MALT lymphoma ${ }^{(11}$, 18, 22). The discovery of a causative role for $H$. pylori in the development of gastric marginal zone lymphoma of the MALT type has dramatically altered the therapeutic approach to patients with early stage disease. Durable complete remission might be achieved in up to $80 \%$ in patients with early stage MALT lymphoma following eradication of the bacteria ${ }^{(11,18)}$. Conservative anti- $H$. pylori therapy may regress early-stage gastric lymphoma to some degree, but not completely ${ }^{(11)}$. The effect is considered insufficient in the case of lymphoma invasion beyond the submucosa of the stomach and a pretreatment diagnosis of the depth of lymphoma invasion is difficult ${ }^{(18)}$. Besides which, the duration of this response remains unknown and long-term follow-up studies are needed for cases treated without surgery. Radiotherapy, chemotherapy or surgery has been tried in patients that failed to respond to H. pylori eradication, or that had a low grade of gastric MALT lymphoma without $H$. pylori infection ${ }^{(11,15,18)}$.

In most series, the poor prognostic factors for primary gastric lymphoma are considered to be high histological grade, involvement of lymph nodes, incomplete extirpation of the neoplasm, primary lesion greater than $10 \mathrm{~cm}$ in diameter and invasion of the serous membrane or adjacent organs ${ }^{(1,2,4,33)}$. On the other hand, good prognosis was associated with low-grade disease, age below 65 years, free surgical margins in cases of resection, and achievement of initial complete remission ${ }^{(1,2,3,13,27,33,34)}$.

The overall 5-year survival for patients considered in the present study who presented primary gastric lymphoma in stage IE and IIE1 was 56.2\%, although the 5-year survival found in the literature range 52 to $93 \%(2,3,4,31,32,33)$. Indeed, the survival rates reach $60 \%$ with surgery alone, $85 \%$ with surgery plus adjuvant chemotherapy ${ }^{(26)}$, and $86 \%-94 \%$ for combined surgery and chemotherapy in stages IE and $\operatorname{IIE}^{(13,31,34)}$. This difference found in the present study may disclose the high rate of postoperative complications $(25 \%)$ and the patients $(2 / 12,5 \%)$ with more advanced local disease whose survival less than 5 years. In the present sample, four patients, all elderly, died due to postoperative complications. Two of them (cases 9 and 13), both 73 years of age, presented large and localized gastric lesions in the body of the organ, which motivated the performing of total gastrectomy associated to splenectomy and corporeal-caudal pancreatectomy. The third patient (case 10), 67 years old and submitted to subtotal gastrectomy, presented an extensive lesion and high degree of neoplasia, with infiltration of the serosa of stomach. The fourth patient (case 15), 83 years old, was submitted to subtotal gastrectomy for multiple gastric lesions. All four of these patients presented comorbidities, a fact that probably influenced the unfavorable postoperative course. In addition, it should be considered that, since this was a historical series, recent improvements in the intra-operative care and especially in the postoperative period could have lowered the rate of complications and mortality in this particular series. Another two patients, both presenting stage IIE1 and invasion of the serosa of stomach, whose lesions reached $6.0 \mathrm{~cm}$ and $10 \mathrm{~cm}$ in the largest diameter, died 3 years and 3.5 years, respectively, after removal of the neoplasia, both due to peritoneal recurrence. Involvement of 
the lymph nodes and invasion of the serosa of the organ and the expressive dimensions of the neoplasias must have contributed to the fact that these patients developed carcinomatosis. On the other hand, all the other patients with stage IE reached 5 years of survival without recurrence of the neoplasia.

Involvement of the lymph nodes and absence of adjuvant

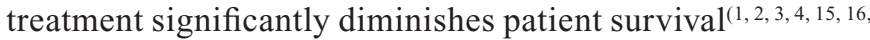
$31,32,33)$, as was observed in the present series, and probably because of the small number of patients in each subgroup, it was not possible to obtain definitive results regarding the influence of these variables on the prognosis for patients with primary gastric lymphoma.

Because primary early-stage gastric lymphoma is only rarely observed in each treatment center, only cooperative prospective multicentric studies may gain sufficient statistical power to form conclusions, regarding the best means of increasing the cure rate and reducing side effects from the treatment while also considering the patients' quality of life ${ }^{(33)}$.

\section{CONCLUSIONS}

Among the patients with primary early-stage gastric lymphoma (IE and IIE1), this study, albeit with a limited number of patients, demonstrated that gastric resection permitted extirpation of the lesion together with an accurate clinicopathological staging and provided sufficient material for histopathological study. For patients with localized primary gastric lymphoma in stage IE, the gastric resection plus adjuvant therapy was associated with a 5-year survival. However, until prospective randomized studies are realized in order to evaluate the real efficacy of the various treatment strategies for primary early-stage gastric lymphoma, management programs should be individually tailored for each patient.

\section{ACKNOWLEDGEMENT}

The authors are grateful to Dr. Marcelo Mester for his technical support.

Waisberg J, André EA, Franco MIF, Abucham-Neto JZ, Wickbold D, Goffi FS. Ressecção curativa associada à quimioterapia adjuvante para o linfoma gástrico primário não-Hodgkin em estádio inicial: estudo retrospectivo com ênfase nos fatores prognósticos e resultado do tratamento. Arq Gastroenterol. 2006;43(1):30-6.

RESUMO - Racional - A terapêutica do linfoma não-Hodgkin gástrico primário é controversa, com defensores da extirpação cirúrgica, da radioterapia e quimioterapia isoladas ou combinadas, especialmente em relação aos estádios mais iniciais. Objetivos - Analisar as características clínico-patológicas e os resultados do tratamento nos doentes operados no Serviço de Gastroenterologia Cirúrgica do Hospital do Servidor Público Estadual, São Paulo, SP, com linfoma gástrico primário em estádio inicial. Realizar revisão da literatura, destacando os aspectos diagnósticos, fatores prognósticos e o papel das diferentes modalidades de tratamento. Método - Dezesseis doentes com linfoma gástrico primário no estádio inicial foram submetidos ao tratamento cirúrgico curativo. Idade, sexo, localização, tamanho, tipo de operação, número de lesões, profundidade da invasão, tipo histológico de acordo com a classificação de Kiel, comprometimento linfonodal, estádio pela classificação de Ann Arbor modificada por Musshoff e Schmidt-Vollmer, grau histológico, margens, terapia adjuvante, evolução e sobrevivência. Resultados - Dez (62,5\%) doentes foram submetidos a gastrectomia subtotal e seis (37,5\%) a gastrectomia total. A maioria $(9 / 56,2 \%)$ das lesões estava localizada no antro. Lesões únicas (10/62,5\%) foram mais freqüentes que as múltiplas $(6 / 37,5 \%)$. Treze doentes $(81,2 \%)$ foram classificados no estádio IE e três $(18,7 \%)$ no estádio IIE1. Dez $(62,5 \%)$ enfermos apresentaram linfoma gástrico primário de baixo grau e seis $(37,5 \%)$ de alto grau. Os tipos histológicos mais freqüentes foram o linfoplasmocítico citóide (4/25.0\%) e o centroblástico (4/25,0\%). Dez doentes (62,5\%) receberam tratamento adjuvante (quimioterapia e/ou radioterapia). Nove enfermos (56,2\%), todos no estádio IE, atingiram sobrevivência maior que 5 anos e oito $(50,0 \%)$ receberam tratamento adjuvante. Dois (12,5\%) doentes no estádio IIE1 tiveram recidiva peritonial e faleceram 3,0 anos e 3,5 anos após suas respectivas operações. A média global de sobrevivência foi de 42,5 meses. Conclusões - Nos doentes com linfoma gástrico primário em estádio inicial (IE e IIE1), a extirpação gástrica permitiu o estádio clinico-patológico acurado, a obtenção de material para o estudo anatomopatológico, a extirpação da lesão e, para enfermos com doença no estádio IE, a extirpação gástrica combinada com terapia adjuvante foi associada com sobrevivência maior que 5 anos. Até que estudos prospectivos casualizados sejam realizados para avaliar a eficácia dos diferentes tipos de tratamento do linfoma gástrico primário em estádio inicial, os protocolos de tratamento devem ser adaptados individualmente.

DESCRITORES - Linfoma não-Hodgkin. Neoplasias gástricas. Fatores prognósticos. Sobrevida. 


\section{REFERENCES}

1. Al-Akwaa AM, Siddiqui N, Al-Mofleh IA. Primary gastric lymphoma. World J Gastroenterol. 2004;10:5-11.

2. Bartlett DL, Karpeh MS Jr, Filippa DA, Brennan MF. Long-term follow-up after curative surgery for early gastric lymphoma. Ann Surg. 1996;223:53-62.

3. Ben-Yosef R, Hoppe RT. Treatment of early-stage gastric lymphoma. J Surg Oncol 1994;57:78-86.

4. Brands F, Mönig SP, Raab M. Treatment and prognosis of gastric lymphoma. Eur J Surg. 1997; 163:803-13

5. Calleti G, Ferrari A, Brocchi E, Barbara L. Accuracy of endoscopic ultrasonography in the diagnostic and staging of gastric cancer and lymphoma. Surgery. 1993;113:14-27.

6. Cordeiro F, Dias H, Leão GC, Robalinho G, Domingues ALC. Linfoma näo-Hodgkin acometendo o estômago e o bulbo duodenal: relato de um caso com evolução de 18 meses. Rev Bras Cancerol. 1993;39:135-6.

7. Dawson IMP, Cornes JS, Morson BC. Primary malignant lymphoid tumors of the intestinal tract. Report of 37 cases with a study of factors influencing prognosis. $\mathrm{Br}$ J Surg. 1961;49:80-9.

8. Ferreri AJ, Ponzoni M, Cordio S, Vanzulli A, Garuti E, Villa E. Low sensitivity of computed tomography in the staging of gastric lymphomas of mucosa-associated lymphoid tissue: impact on prospective trials and ordinary clinical practice. Am J Clin Oncol. 1998;21:614-6.

9. Ferreri AJ, Cardio S, Paro S, Ponzoni M, Freschi M, Veglia F, Villa E. Therapeutic management of stage I-II high-grade primary gastric lymphomas. Oncology. 1999;56:274-82.

10. Ferreri AJ, Cardio S, Ponzoni M, Villa E. Non-surgical treatment with primary chemotherapy, with or without radiation therapy of stage I-II high-grade lymphoma. Leuk Lymphoma. 1999;22:531-41.

11. Fung CY, Grossbard ML, Linggood RM, Younger J, Flieder A, Harris NL, GraemeCook F. Mucosa-associated lymphoid tissue lymphoma of the stomach: long-term outcome after local treatment. Cancer. 1999;85:9-17.

12. Furtado JP, Pitrez FA, W. Filho, Zygmunt. Linfomas primários do estômago: casuística e discussão. Rev Bras Cancerol. 1994;40:13-9.

13. Gospodarowicz MK, Sutcliffe SB, Clark RM, Dembo AJ, Patterson BJ, Fitzpatrick PJ, Chua T, Bush RS. Outcome analysis of localized gastrointestinal lymphoma treated with surgery and postoperative irradiation. Int J Radiat Oncol Biol Phys. 1990;19:1351-5.

14. Hashimoto MS, Sakai P, Lima CH, Nakauchi JK, Ishioka S, Iriya K, Rodrigues JG, Pinotti HW. Linfoma gástrico primário: valor da endoscopia para o diagnóstico. GED Gastroenterol Endosc Dig. 1986;5:45-8

15. Ishizuka H, Kubota T, Hayashi, Otany Y, Kumai K, Kitajima M. Management of primary gastric lymphoma from a surgeon's viewpoint. Oncol Rep. 1999;6:103-6.

16. Jones RE, Willis S, Innes DJ, Wanebo HJ. Primary gastric lymphoma - Problems in staging and management. Am J Surg. 1998;155:118-23.

17. Kitamura K, Yamaguchi T, Okamoto K, Ichikawa D, Hoshima M, Tanigushi H, Takahashi T. Early gastric lymphoma: a clinicopathologic study of ten patients, literature review, and comparison with early gastric adenocarcinoma. Cancer. 1996;7:850-7.

18. Lee SK, Lee YC, Chung JB, Chon CY, Moon YM, Kang JK, Park I-S, Suh CO, Yang WI. Low grade gastric mucosa associated lymphoid tissue lymphoma: treatment strategies based on 10-year follow-up. World J Gastroenterol. 2004;10:223-6.

19. Maor MH, Maddux B, Osborne BM, Fuller LM, Sullivan JA, Nelson RS, Martin RG Libshitz HI, Velasquez WS, Bennett RW. Stages IE and IIE non-Hodgkin's lymphoma of the stomach. Comparison of treatment modalities. Cancer. 1984;54:2330-7.

20. Maor MH, Velasquez WS, Fuller LM, Silvermintz KB. Stomach conservation in stages IE and IIE gastric non-Hodgkin's lymphoma. J Clin Oncol. 1990;8:266-71.

21. Musshoff K, Schmidt-Vollmer H. Proceeding: Prognosis of non-Hodgkin's lymphomas with special emphasis on the staging classification. Z Krebsforsch Clin Onkol Cancer Res Clin Oncol. 1975;83:323-41.
22. Nakamura T, Inagaki H, Seto M, Nakamura S. Gastric low-grade B-cell MALT lymphoma: treatment, response, and genetic alteration. J Gastroenterol. 2003;38:921-9.

23. Nita ME, Mester M, Machado MAC, Iriya K, Benetti CP, Waitzberg DL, Gama Rodrigues JJ, Pinotti HW. Regressão total de linfoma gástrico avançado após quimioterapia. Rev Hosp Clin Fac Med Univ São Paulo. 1994;49:221-4.

24. Popescu RA, Wotherspoon AC, Cunningham D, Norman A, Prendiville J, Hill ME. Surgery plus chemotherapy or chemotherapy alone for primary intermediate and high-grade gastric non-Hodgkin's lymphoma; The Royal Marsden Hospital experience. Eur J Cancer. 1999;35:928-34

25. Raderer M, Valencak J, Österreicher C, Drach J, Hejna M, Kornek G, Scheithaue W, Brodowicz T, Chott A, Dragosics B. Chemotherapy for the treatment of patients with primary high grade gastric B-cell lymphoma of modified Ann Arbor stages IE and IIE. Cancer. 2000;88:1979-85.

26. Salles G, Herbrecht R, Tilly H, Berger F, Brousse N, Gisselbrecht C, Coiffier B Aggressive primary gastrointestinal lymphomas: review of 91 patients treated with the LNH-84 regimen. A study of the Groupe-d'Etude des Lymphomes Agressifs. Am J Med. 1991;90:77-84.

27. Salvagno L, Soraru M, Busetto M, Puccetti C, Sava C, Endrizzi L, Giusto M, Aversa S, Sileni VC, Polico R, Bianco A, Rupolo M, Nitti D, Doglioni C, Lise M. Gastric non-Hodgkin's lymphomas: analysis of 252 patients from a multicenter study. Tumori. 1999;85:113-21.

28. Schwarz RJ, Conners JM, Schmidt N. Diagnosis and management of stage IE and stage IIE gastric lymphomas. Am J Surg. 1993;165:561-5.

29. Shepherd FA, Evans WK, Kutas G, Yau JC, Dang P, Scott JG, Farquharson HA Framcombe WH, Bailey D, Baker MA. Chemotherapy following surgery for stages IE and IIE non-Hodgkin's lymphoma of the gastrointestinal tract. J Clin Oncol. 1988;6:253-60

30. Suekane H, Iida M, Kuwano Y, Kohrogi N, Yao T, Iwashita A, Fujishima M. Diagnosis of primary early gastric lymphoma. Usefulness of endoscopic mucosal resection for histologic evaluation. Cancer. 1993;71:1207-13.

31. Takahashi I, Maehara Y, Koga T, Sumiyoshi Y, Oshiro T, Baba H, Kohnoe S, Okamura T, Uike N, Matsuhara T, Kume K, Sugimachi K. Role of surgery in the patients with stage I and II primary gastric lymphoma. Hepatogastroenterology. 2003;50:877-82.

32. Tanaka Y, Takao T, Watanabe H, Kido T, Ogawa N, Imase K, Sunada S, Sando K, Kawamoto S, Koto K, Satani M, Ono N. Early stage gastric lymphoma: is operation essential? World J Surg. 1994;18:896-9.

33. Vaillant JC, Ruskoné-Fourmestraux A, Aegerter P, Gayet B, Rambaud JC, Valleur P, Pare R. Management and long-term results of surgery for localized gastric lymphomas. Am J Surg. 2000;179:216-22.

34. Vigliotti ML, Dell'olio, Romano G, Tartarone A, D'arena G, Carela AM, Di Renzo N. Primary gastric lymphoma for stage I/II1 E: operative and conservative management in retrospective data from 71 cases. Leuk Lymphoma. 2003;44:1259-61.

35. Vilela SM, Kestenberg D, Behar R, Elias RV, Maciel RA. Linfoma gástrico em paciente jovem. J Bras Med. 1984;47:72-4.

36. Waisberg J, Bromberg SH, Franco MIF, Stephani SM, Zanoto A, Godoy AC, Goffi FS. The role of surgery in the treatment of primary gastric lymphoma. Int Surg. 2000;85:219-25.

37. Waisberg J, Bromberg SH, Stephani SM, Franco MIF, Godoy AC, Goffi FS. Tratamento cirúrgico do linfoma gástrico primário. Rev Col Bras Cir. 2001;28:125-32. 